\title{
Formation and Evolution of Silicate Inclusions in Molten Steel by Magnesium Treatment
}

\author{
Qingsong ZHANG, Yi MIN, ${ }^{*}$ Haisheng XU, Jiujian XU and Chengjun LIU \\ Key Laboratory for Ecological Metallurgy of Multimetallic Ores (Ministry of Education), Northeastern University, Shenyang, \\ 110819 P.R. China.
}

(Received on August 3, 2018; accepted on October 29, 2018; J-STAGE Advance published date: December 19, 2018)

\begin{abstract}
The effect of magnesium addition on the formation and evolution of inclusions in Mn-Si killed steel is studied by laboratory experiments and thermodynamic calculation. Samples were taken at different holding time after magnesium addition to study the transient evolution of inclusions. The morphology, composition, number and diameter of inclusions were thoroughly analyzed by SEM-EDS. The results show that four types of inclusions ( $\mathrm{MgO}-\mathrm{SiO}_{2}-\mathrm{MnO}$ liquid inclusion, $\mathrm{MgO}-\mathrm{SiO}_{2}-\mathrm{MnO}$ complex inclusion, $\mathrm{MgO}_{-} \mathrm{SiO}_{2}$ and $\mathrm{MgO}$ solid inclusion) form with different amount of magnesium addition. Liquid inclusion of $\mathrm{MnO}-\mathrm{SiO}_{2}$ is promptly modified to $\mathrm{MgO}-\mathrm{SiO}_{2}-\mathrm{MnO}$ liquid inclusion with $0.0005 \%$ magnesium addition. As the amount of magnesium is increased to $0.0011 \%$, intermediate product $\mathrm{MgO}$ forms immediately and then gradually transforms to $\mathrm{MgO}-\mathrm{SiO}_{2}$ solid inclusion with holding time. While $\mathrm{MgO}$ solid inclusion keeps stable throughout with $0.0019 \%$ magnesium addition.
\end{abstract}

KEY WORDS: magnesium treatment; silicate inclusions; thermodynamics.

\section{Introduction}

The presence of inclusion in steel has an adverse influence on the plasticity, toughness and fatigue life of steel. Beside, inclusion would deteriorate the castability of molten steel and severely affect the production process. ${ }^{1,2)}$ In order to improve the performance of steel, it is necessary to control the composition, number and size of the residual inclusion in steel.

Calcium is generally used in steelworks to modify nondeformable $\mathrm{Al}_{2} \mathrm{O}_{3}$ inclusion to calcium aluminate system inclusion with low melting point. ${ }^{3,4)}$ However, there are still some limitations for the application of calcium treatment. For instance, calcium treatment is prohibited in bearing steel production process due to the adverse effect of calcium aluminate inclusion on the fatigue life of steel. ${ }^{5)}$ During the production of high sulfur steel, the problem of nozzle clogging is still serious owing to the precipitation of $\left.\mathrm{CaS}^{6}{ }^{6}\right)$ Thence, magnesium treatment has gained more and more attentions as the replacement of calcium treatment.

Similar to calcium, magnesium also has strong affinity to oxygen in steel at the steelmaking temperature. In recent years, many investigations have focused on the modification of $\mathrm{Al}_{2} \mathrm{O}_{3}$ based inclusion by magnesium treatment. $^{7-10)} \mathrm{A}$ number of thermodynamic studies on the formation of $\mathrm{MgO} \cdot \mathrm{Al}_{2} \mathrm{O}_{3}$ were carried out. ${ }^{11,12)} \mathrm{Zhang}$ et al. ${ }^{13)}$ reviewed the reported calculation for the stability diagram of $\mathrm{Al}-\mathrm{Mg}-\mathrm{O}$ system inclusion at steelmaking temperature.

\footnotetext{
* Corresponding author: E-mail: miny@smm.neu.edu.cn DOI: https://doi.org/10.2355/isijinternational.ISIJINT-2018-543
}

Kimura et al. ${ }^{14)}$ reported that $\mathrm{MgO}-\mathrm{Al}_{2} \mathrm{O}_{3}$ complex inclusion had a much weaker tendency to aggregate and form clusters than $\mathrm{Al}_{2} \mathrm{O}_{3}$ inclusion by the in-situ observation with a confocal scanning laser microscope. Zhang et al. ${ }^{15)}$ studied the effect of magnesium addition on the evolution of inclusion in $\mathrm{Al}-\mathrm{Ca}$ deoxidized melts, and found that the size of oxide inclusion could be controlled well with a certain amount of magnesium addition. Similar results were also reported by Zhang et al. ${ }^{16)}$ in $\mathrm{Mn}-\mathrm{Si}-\mathrm{Al}$ deoxidized molten steel. Kim et $a l .{ }^{17)}$ and Chang et al. ${ }^{18)}$ investigated the effect of magnesium on the evolution of inclusion in $\mathrm{Mn}-\mathrm{Si}-\mathrm{Ti}$ deoxidized low carbon steel using induction melting furnace. It is found that the phase of inclusion changed sequentially in the path of $\mathrm{Ti}_{2} \mathrm{O}_{3} \rightarrow \mathrm{Ti}-\mathrm{Mg}-\mathrm{O} \rightarrow \mathrm{MgTiO}_{3} \rightarrow \mathrm{MgO}$ with the increase of magnesium content. Wen et al. ${ }^{19)}$ observed the effect of $\mathrm{Si}-\mathrm{Mg}$ alloy on inclusion and microstructure of 16 $\mathrm{Mn}$ steel. The result indicated that inclusion transformed into $\mathrm{MgAl}_{2} \mathrm{O}_{4}$ and $\mathrm{MgO}$ after treated by $\mathrm{Si}-\mathrm{Mg}$ alloy. The research of magnesium treatment is mainly concentrated on Al killed steel, however few studies have been carried out for $\mathrm{Mn}-\mathrm{Si}$ killed steel. In the production of semi-killed steel, Mn-Si deoxidization is usually adopted to avoid the precipitation of high melting point inclusion, however, the formation and evolution mechanism of silicate inclusion by magnesium treatment has not been elucidated yet.

In the current study, laboratory experiments were carried out to study the effect of magnesium addition on inclusions in $\mathrm{Mn}-\mathrm{Si}$ killed molten steel. The type, composition, number and diameter of inclusions at different holding time were investigated comprehensively. The results from present work are significant for understanding and controlling 
silicate inclusions by magnesium treatment.

\section{Experimental Methods}

\subsection{Experimental Procedures}

The experiments were carried out in a tube furnace, which was heated by $\mathrm{MoSi}_{2}$ rods with two B-type thermocouples, as shown in Fig. 1. Approximately $450 \mathrm{~g}$ industrial pure iron was melted in $\mathrm{MgO}$ crucible under high pure argon atmosphere $(99.99 \%)$ at $1873 \mathrm{~K}$. After $30 \mathrm{~min}$ stabilization of the melt, the initial dissolved oxygen $\left([\mathrm{O}]_{1}\right)$ was detected by electrolyte oxygen probe. Then $\mathrm{Mn}-\mathrm{Fe}$ alloy and pure silicon were successively added to the molten steel to deoxidize. 5 min later, first sample (S0) was sucked out by a quartz tube and immediately quenched in ice-water bath. Subsequently, Ni-Mg alloy was quickly inserted to the melt and three samples (S1, S2 and S3) were taken at 1 min, 5 min and $10 \mathrm{~min}$ after magnesium addition, respectively. The final dissolved oxygen $\left([\mathrm{O}]_{2}\right)$ was then determined after magnesium addition. Thereafter, the melt cooled to the room temperature by cutting off the power supply to the furnace. Three sets of experiments (A, B and C) with different amount of magnesium were performed. The detailed procedures of present experiments are provided in Fig. 2. The compositions of raw material used in the experiments are listed in Table 1.

\subsection{Detection Methods for Steel Composition and Inclusions}

The residual steel samples in $\mathrm{MgO}$ crucible were chosen to analyze the contents of silicon, manganese and magnesium by the inductively coupled plasma optical emission

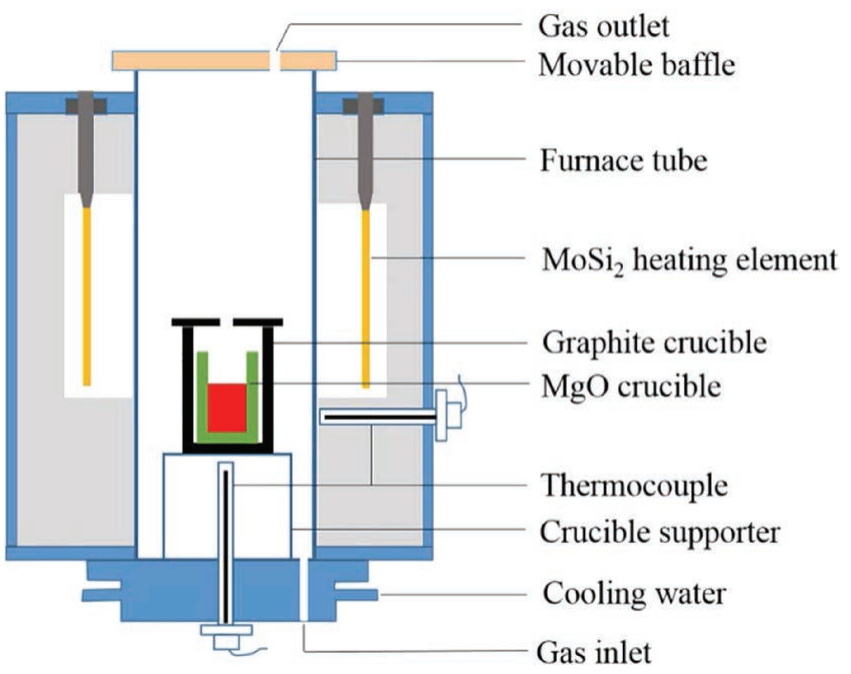

Fig. 1. Schematic diagram of tube furnace. (Online version in color.) spectrometer (ICP-OES). Oxygen activities in the molten steel were directly measured by solid electrolyte concentration cell method in 8-15 s without sampling. Figure 3 shows the working principle of the oxygen concentration cell. Due to the difference in oxygen partial pressure between the two half cells, $\mathrm{O}^{2-}$ migrates between the two half cells, thereby generating an electromotive force. The electromotive force is subject to Nernst's Equation, as shown in Eq. (1). Based on Eq. (1), the general function of oxygen concentration and the electromotive force is given in Eq. (2). ${ }^{20)}$

$$
E=\frac{R T}{n F} \ln \frac{a_{[\mathrm{O}]}}{P_{\mathrm{O}_{2}}^{1 / 2}}
$$

Where $E$ - electromotive force, $\mathrm{mV} ; R$-ideal gas constant; $T$ temperature, $\mathrm{K} ; n$ - reference electrode moles; $F$ - Coulomb constant; $a_{[\mathrm{O}]}$-oxygen concentration, ppm; $P_{\mathrm{O}_{2}}$-oxygen partial pressure, $\mathrm{Pa}$.

$$
\begin{aligned}
& a_{[O]}=10^{-\left(a_{0}+b_{0} / T\right)} \\
& \left\{\frac{10^{(a+b / T) / 4}+10^{\left(a_{1}-b_{1} / T\right) / 4}}{10^{5.04\left(E+a_{2}-b_{2} t\right) / T}}-10^{\left(a_{1}-b_{1} / T\right) / 4}\right\}^{2} \times 10^{4}
\end{aligned}
$$

Where $t$-temperature, ${ }^{\circ} \mathrm{C} ; a_{0}, b_{0}$-measured medium coefficient; $a, b$-reference material coefficient; $a_{1}, b_{1}$-solid electrolyte coefficient; $a_{2}, b_{2}$-conductor coefficient.

After all the experiments, the molten steel samples were

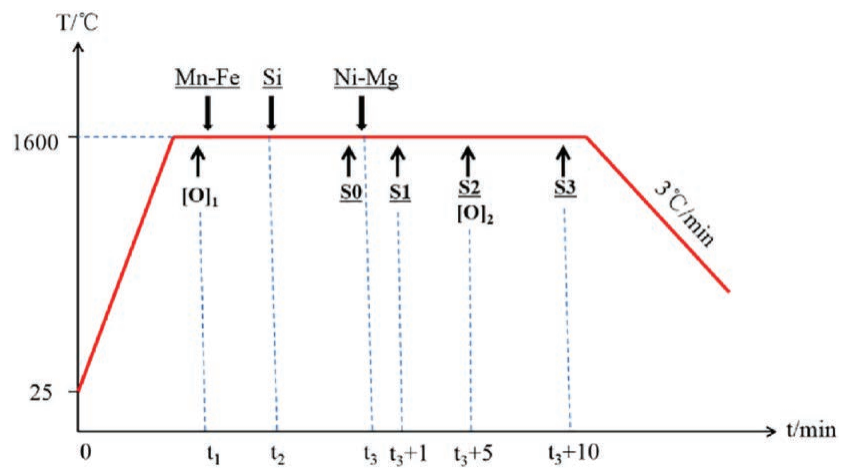

Fig. 2. Procedure of the experiments. (Online version in color.)

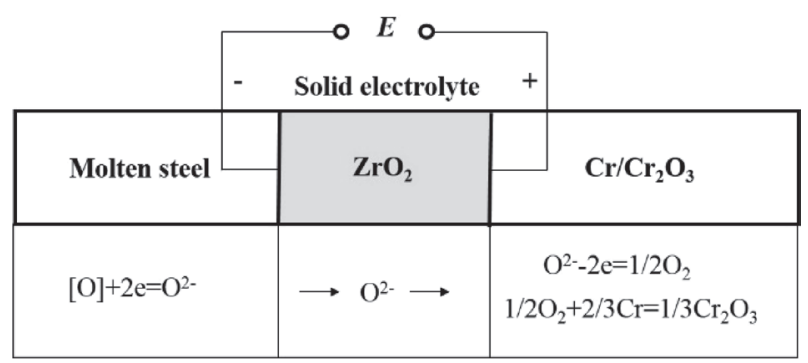

Fig. 3. Working principle of the oxygen concentration cell.

Table 1. Chemical compositions of raw material, wt.\%.

\begin{tabular}{cccccccccc}
\hline Raw material & $\mathrm{Fe}$ & $\mathrm{Ni}$ & $\mathrm{Al}$ & $\mathrm{Mn}$ & $\mathrm{C}$ & $\mathrm{Si}$ & $\mathrm{Mg}$ & $\mathrm{S}$ & Balance \\
\hline Industrial pure iron & 99.90 & 0.01 & 0.018 & 0.03 & 0.0021 & 0.01 & - & 0.003 & 0.035 \\
Mn-Fe alloy & 12.57 & & & 84.20 & 1.50 & 1.50 & - & 0.03 & \\
Pure silicon & & & & & & 99.90 & & & 0.10 \\
Ni-Mg alloy & 0.93 & 80.12 & & & & & 17.98 & & 0.97 \\
\hline
\end{tabular}


grinned on abrasive papers and then polished on polishing machine. Afterwards, the two-dimensional morphology and internal composition of inclusions were analysed by the field emission scanning electron microscope (FE-SEM) and energy dispersive spectrometer (EDS).

Image analysis software Image Pro Plus 6.0 was used to count the number and diameter of inclusions. The diameter of inclusion was estimated as the diameter of a circle with the same area. ${ }^{21)}$ The total observed area of each sample was $1.2 \mathrm{~mm}^{2}$, which corresponded to 108 observation areas at the magnification of 2000 obtained by FE-SEM.

\section{Results and Discussion}

\subsection{Chemical Composition of Steel}

Table 2 lists the measured compositions of magnesium, silicon and manganese in steel. It is obviously seen that the mass fraction of manganese and silicon in three melts are at the same level, which is about $1.2 \%$ and $0.2 \%$, respectively. In order to investigate the effect of magnesium content on the evolution of inclusion, different quantity of $\mathrm{Ni}-\mathrm{Mg}$ alloy was added to the molten steel. The analysis results

Table 2. Chemical compositions in different melts, wt.\%.

\begin{tabular}{cccccc}
\hline Melt & $\mathrm{Mn}$ & $\mathrm{Si}$ & $\mathrm{Mg}$ & {$[\mathrm{O}]_{1}$} & {$[\mathrm{O}]_{2}$} \\
\hline $\mathrm{A}$ & 1.19 & 0.203 & 0.0005 & 0.0163 & 0.0033 \\
$\mathrm{~B}$ & 1.31 & 0.194 & 0.0011 & 0.0160 & 0.0035 \\
$\mathrm{C}$ & 1.22 & 0.187 & 0.0019 & 0.0167 & 0.0018 \\
\hline
\end{tabular}

$[\mathrm{O}]_{1}$ the initial dissolved oxygen, $[\mathrm{O}]_{2}$ the final dissolved oxygen show that magnesium content in different melt are at three different levels in the range of $0.0005 \%$ to $0.0019 \%$. Ni in the $\mathrm{Ni}-\mathrm{Mg}$ alloy does not affect the experimental results. On the one hand, when the amount of $\mathrm{Ni}$ introduced is low $\left(w_{N i}<0.3 \%\right)$, the oxidation of $\mathrm{Ni}$ does not occur in the molten steel according to the thermodynamic calculation. On the other hand, the influence of $\mathrm{Ni}$ on the formation and evolution of inclusions can be neglected because of the small interaction coefficients between $\mathrm{Ni}$ and other elements such as $\mathrm{Si}$ and $\mathrm{Mg}$. The initial dissolved oxygen in molten steel is $0.016-0.017 \%$ and the final dissolved oxygen decreases to below $0.0035 \%$.

\subsection{Characteristics of Inclusions}

\subsubsection{Types of Inclusions in Steel}

There are five types of inclusions observed in Melt A to Melt C. The typical morphology and EDS spectra of each type of inclusion are presented in Figs. 4 to 8.

The typical inclusion found in the sample S0 after silicon addition is Type $1 \mathrm{SiO}_{2}-\mathrm{MnO}$ system inclusion. Figure 4 presents the typical morphology of Type 1, which is in spherical shape. The composition analysis results and $\mathrm{SiO}_{2}-\mathrm{MnO}$ phase diagram ${ }^{22}$ indicate that Type 1 inclusion is in liquid phase.

Type 2 inclusion is $\mathrm{MgO}-\mathrm{SiO}_{2}-\mathrm{MnO}$ system, as shown in Fig. 5. Type 2 inclusion is mainly detected in S1, S2 and $\mathrm{S} 3$ of Melt A with trace amount of magnesium addition. The EDS analysis results show that Type 2 inclusion contains a small amount of magnesium and the mass fraction is 5\% with the atomic ratio of $\mathrm{Mg} / \mathrm{Si}$ about 0.35 . The uniform element distributions of $\mathrm{Mn}, \mathrm{Si}, \mathrm{Mg}$ and $\mathrm{O}$ indicate that this
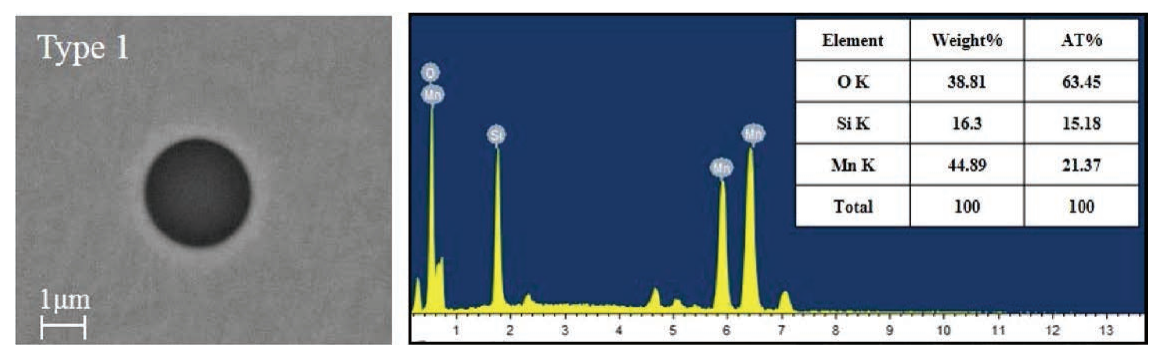

Fig. 4. Type $1 \mathrm{SiO}_{2}-\mathrm{MnO}$ system inclusion. (Online version in color.)
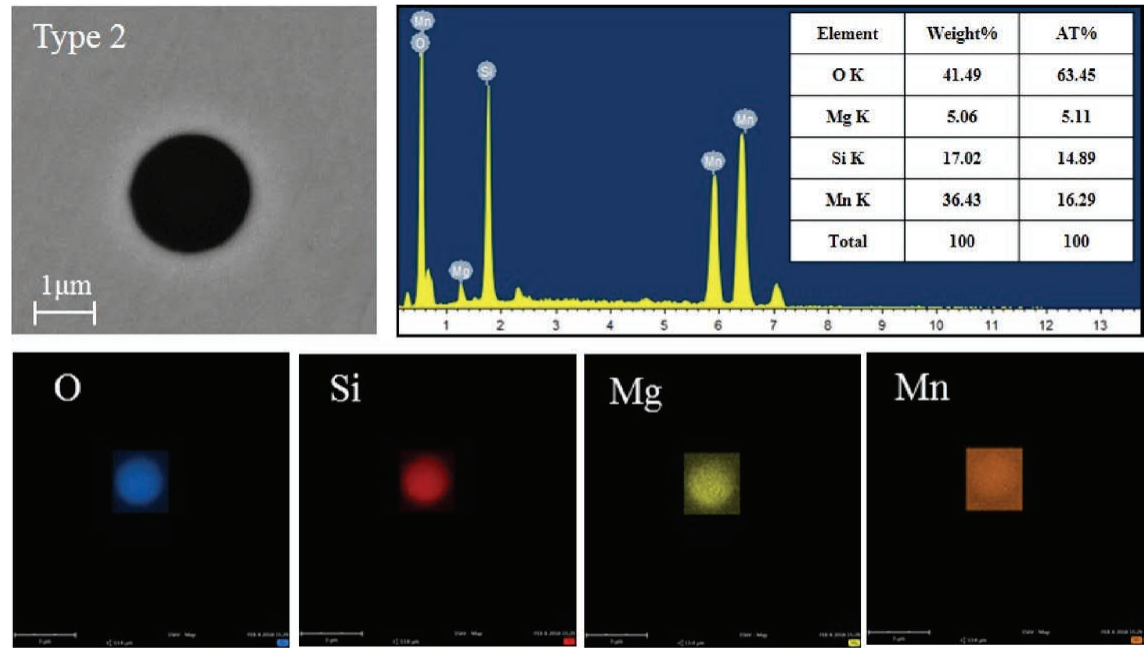

Fig. 5. Type $2 \mathrm{MgO}-\mathrm{SiO}_{2}-\mathrm{MnO}$ system homogeneous inclusion. (Online version in color.) 

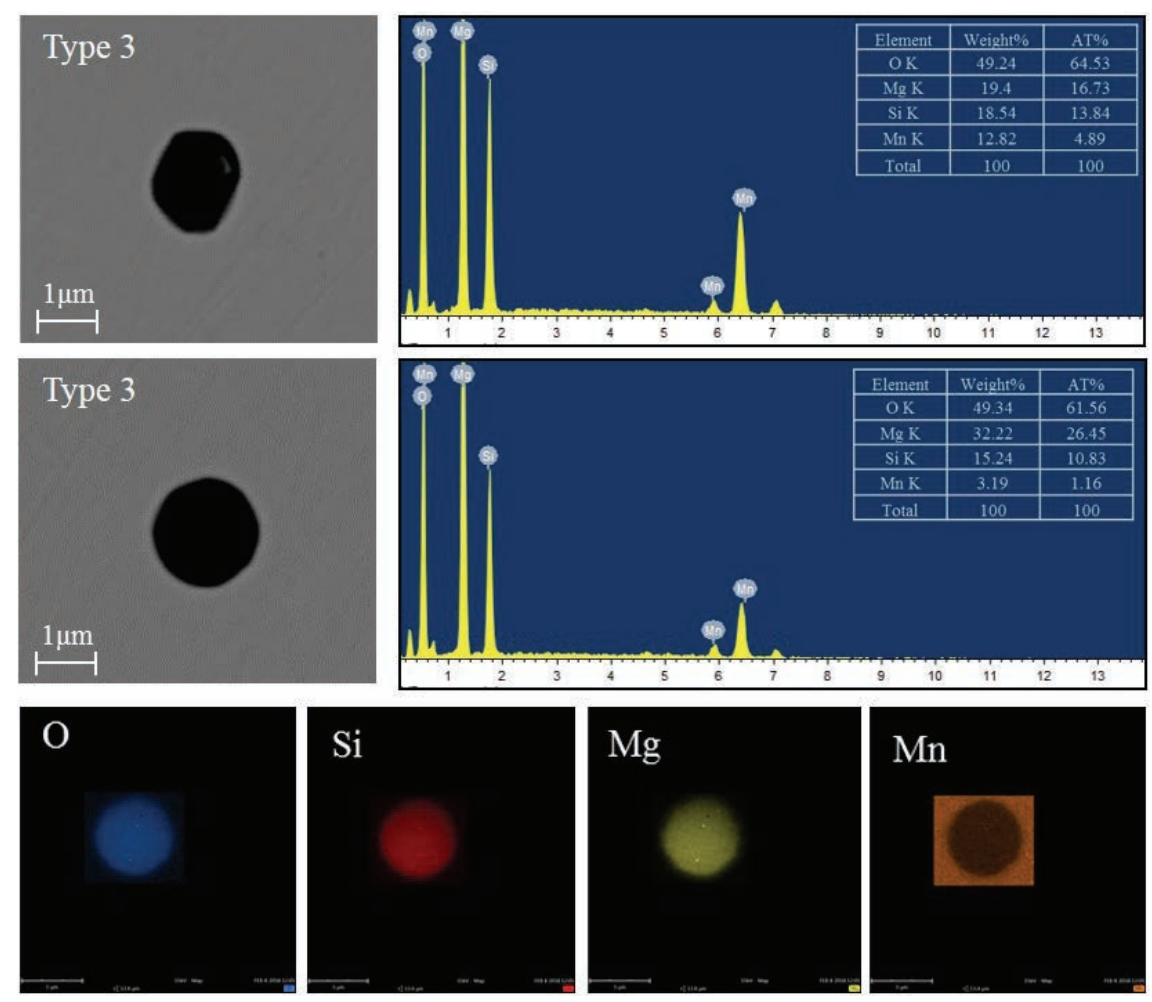

Fig. 6. Type $3 \mathrm{MgO}-\mathrm{SiO}_{2}$ system inclusion. (Online version in color.)
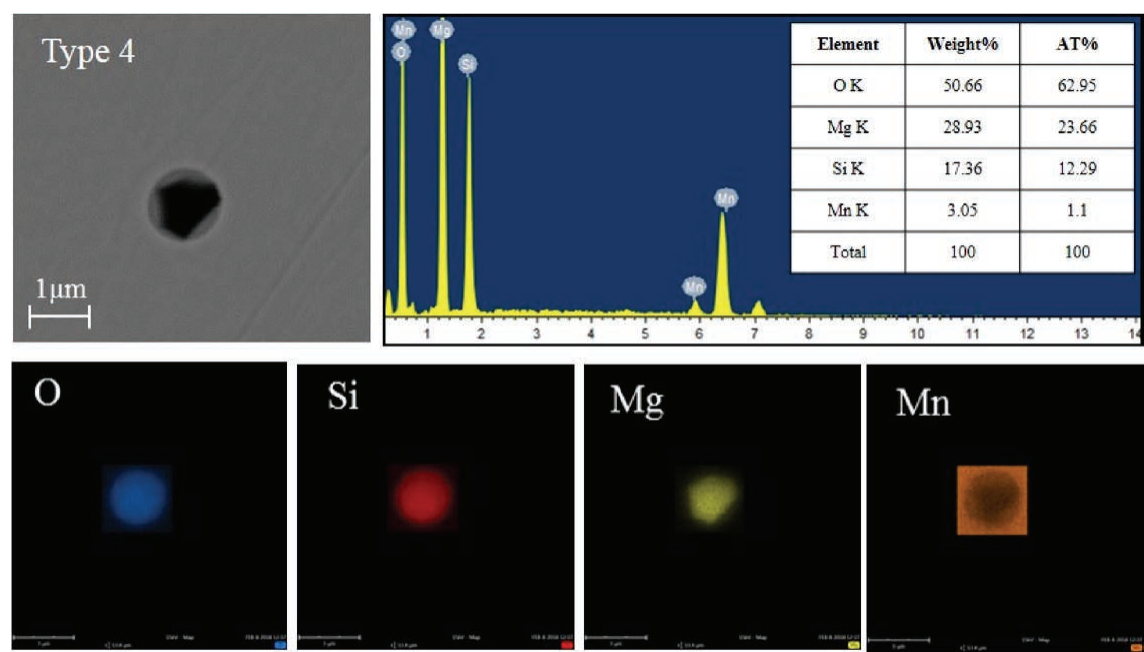

Fig. 7. Type $4 \mathrm{MgO}-\mathrm{SiO}_{2}-\mathrm{MnO}$ system complex inclusion. (Online version in color.)
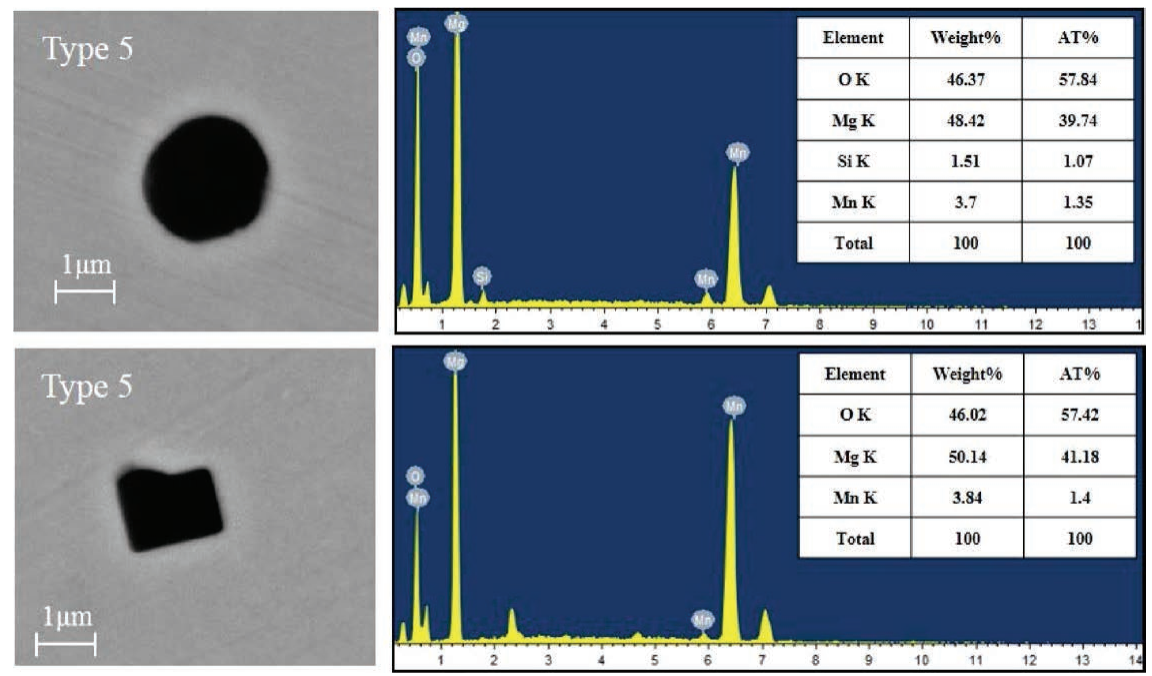

Fig. 8. Type $5 \mathrm{MgO}$ system inclusion. (Online version in color.) 
type of inclusion is homogeneous.

Type 3 inclusion is $\mathrm{MgO}-\mathrm{SiO}_{2}$ system and its typical morphology and composition are given in Fig. 6. The results show that the appearances of Type 3 inclusion are rectangular or spherical. The elemental mappings reveal that Type 3 inclusion is homogeneous and mainly composed of $\mathrm{Mg}$, $\mathrm{Si}$ and $\mathrm{O}$. The EDS analysis results indicate that the mass fraction of magnesium in Type 3 inclusion increases to more than $16 \%$ with the atomic ratio of $\mathrm{Mg} / \mathrm{Si}$ between $1-2$. Type 3 inclusion is mainly observed in S2 and S3 of Melt B with medium amount of magnesium addition.

Type 4 inclusion presented in Fig. 7 is a combination of Type 2 and Type 3. The elemental mappings show that the core of Type 4 is $\mathrm{MgO}-\mathrm{SiO}_{2}$ and surrounded by $\mathrm{MgO}-\mathrm{SiO}_{2}-\mathrm{MnO}$. Type 4 inclusion is globular and mainly detected in $\mathrm{S} 3$ of Melt B.

Type 5 inclusion given in Fig. 8 is $\mathrm{MgO}$ system. Both rectangle and sphere shapes of Type 5 were observed. The spherical Type 5 inclusion is mainly found in S1 of Melt B, while the rectangular Type 5 inclusion is detected in Melt $\mathrm{C}$ with excess magnesium addition. Moreover, the EDS analysis results show that the spherical $\mathrm{MgO}$ system inclusion contains trace amount of silicon.

The distributions of various inclusions in different samples are summarized in Table 3. The number in Table 3 represents the type of inclusion. The results show that $\mathrm{SiO}_{2}-\mathrm{MnO}$ liquid inclusions are modified to $\mathrm{MgO}-\mathrm{SiO}_{2}-$ $\mathrm{MnO}$ and $\mathrm{MgO}$ respectively in Met $\mathrm{A}$ and Melt $\mathrm{C}$. In Melt $\mathrm{B}, \mathrm{MgO}$ forms firstly and then transforms to $\mathrm{SiO}_{2}-\mathrm{MgO}$ with the prolongation of holding time.

\subsubsection{Composition Evolution of Inclusions}

To assess the evolution process of inclusions with holding time after magnesium addition, the EDS analysis results of inclusions were converted to mass percentage of $\mathrm{MgO}, \mathrm{SiO}_{2}$ and $\mathrm{MnO}$, which could be projected into $\mathrm{MgO}-\mathrm{SiO}_{2}-\mathrm{MnO}$ ternary system phase diagram, ${ }^{23)}$ as shown in Fig. 9. In Melt $\mathrm{A}, \mathrm{MgO}-\mathrm{SiO}_{2}-\mathrm{MnO}$ is the main type of inclusions and the compositions are all in the region of liquid, which is shown in Fig. 9(a). The composition distribution of inclusions in Melt B is given in Fig. 9(b). It can be seen that most inclusions distribute in the composition region of $2 \mathrm{MgO} \cdot \mathrm{SiO}_{2}$ saturation. ( $\mathrm{Mg}, \mathrm{Mn}) \mathrm{O}$ solid solutions form immediately at $1 \mathrm{~min}$ after magnesium addition. 5 min later, the mass percentage of $\mathrm{SiO}_{2}$ in inclusions increases and the compositions of inclusions distribute in the region of $2 \mathrm{MgO} \cdot \mathrm{SiO}_{2}$ saturation. $10 \mathrm{~min}$ later, the content of $\mathrm{SiO}_{2}$ in inclusions continues to increase and Type 3 inclusion forms. In Melt $\mathrm{C}$, the inclusions of $(\mathrm{Mg}, \mathrm{Mn}) \mathrm{O}$ solid solutions precipitate and remain stable with the increase of holding time, as shown in Fig. 9(c). Based on the experimental results, it

Table 3. Types of inclusions in different samples.

\begin{tabular}{ccccc}
\hline & S0 & S1 & S2 & S3 \\
\cline { 2 - 5 } Melt & $\begin{array}{c}\text { 5 min after } \\
\text { Si addition }\end{array}$ & $\begin{array}{c}\text { 1 min after } \\
\text { Mg addition }\end{array}$ & $\begin{array}{c}5 \text { min after } \\
\text { Mg addition }\end{array}$ & $\begin{array}{c}\text { 10 min after } \\
\text { Mg addition }\end{array}$ \\
\hline A & 1 & 2 & 2 & 2 \\
B & 1 & 5 & 3 & $3 / 4$ \\
C & 1 & 5 & 5 & 5 \\
\hline
\end{tabular}

can be concluded that the evolution process of inclusion is $\mathrm{MgO}-\mathrm{SiO}_{2}-\mathrm{MnO}(\mathrm{l}) \rightarrow \mathrm{MgO}-\mathrm{SiO}_{2}(\mathrm{~s}) \rightarrow \mathrm{MgO}(\mathrm{s})$ with the increase of magnesium addition.

\subsubsection{Number and Diameter of Inclusions}

Figure 10 shows the effect of magnesium addition on the number and diameter of inclusions, which is plotted against holding time after magnesium addition. The type of inclusion before magnesium addition is $\mathrm{SiO}_{2}-\mathrm{MnO}$ liquid oxide and the average diameter of inclusion is $1.4 \mu \mathrm{m}$ in the sample S0. After magnesium addition, the average diameter of inclusion decreases firstly and then increases with the prolongation of holding time. The similar results were also reported in other studies. ${ }^{16,24,25)}$ It can be clearly seen that the number of inclusions below $2.0 \mu \mathrm{m}$ increases rapidly in the sample $\mathrm{S} 1$. With prolonging holding time, the number of inclusions above $2.0 \mu \mathrm{m}$ increases gradually in the sample S2 and S3. One of the possible reason is that inclusion collides and grows during holding time. Moreover, it is noticed that the number of inclusions above $2.0 \mu \mathrm{m}$ in Melt $\mathrm{B}$ is more than that in Melt A and Melt $\mathrm{C}$. The reason is that $\mathrm{MgO}$ formed in Melt $\mathrm{B}$ is unstable and then reacts with molten steel. With the diffusion of $\mathrm{Si}$ from molten steel, inclusion grows continuously in Melt B.

According to the results in $\mathrm{Mn}-\mathrm{Si}$ killed steel, it can be summarized that appropriate magnesium addition is necessary. In the present magnesium treatment level, a medium amount of magnesium addition would lead to the precipitation of more large size inclusions.

\subsection{Thermodynamic Calculation and Formation Mechanism of Inclusions}

In order to explain the modification mechanism of inclusions with magnesium addition, thermodynamic calculation was carried out at $1873 \mathrm{~K}$ using Fact Sage 7.1 with databases of FactPS, FToxide and FTmisc. ${ }^{26,27)}$ Figure 11 shows the effect of magnesium addition on the equilibrium precipitations in Fe-1.2Mn-0.016O-0.2Si molten steel system. According to the characteristics of precipitations in steel, the evolution process of inclusions can be divided into 5 zones and the related reactions are given in Table $4^{28-30)}$

At zone I, the mass fraction of magnesium addition is low and only $\mathrm{MgO}-\mathrm{SiO}_{2}-\mathrm{MnO}$ exists in the molten steel. The formation of $\mathrm{MgO}-\mathrm{SiO}_{2}-\mathrm{MnO}$ can be given by Eq. (1).

At zone II, both $\mathrm{MgO}-\mathrm{SiO}_{2}-\mathrm{MnO}$ and $2 \mathrm{MgO} \cdot \mathrm{SiO}_{2}$ are the equilibrium precipitations. Part of $\mathrm{MgO}-\mathrm{SiO}_{2}-\mathrm{MnO}$ is modified to $2 \mathrm{MgO} \cdot \mathrm{SiO}_{2}$ by Eq. (2), which leads to a drop in the mass fraction of $\mathrm{MgO}-\mathrm{SiO}_{2}-\mathrm{MnO}$.

At zone III, $\mathrm{MgO}-\mathrm{SiO}_{2}-\mathrm{MnO}$ is completely modified to $2 \mathrm{MgO} \cdot \mathrm{SiO}_{2}$ and only $2 \mathrm{MgO} \cdot \mathrm{SiO}_{2}$ system inclusions exist in the molten steel. With the increase of magnesium addition in steel, the mass fraction of $2 \mathrm{MgO} \cdot \mathrm{SiO}_{2}$ continues to increase through Eq. (3).

At zone $\mathrm{IV}, \mathrm{MgO}$ and $2 \mathrm{MgO} \cdot \mathrm{SiO}_{2}$ are the equilibrium precipitations. The mass fraction of $\mathrm{MgO}$ increases with the decrease of $2 \mathrm{MgO} \cdot \mathrm{SiO}_{2}$, which indicates that the equilibrium precipitation transfers from $2 \mathrm{MgO} \cdot \mathrm{SiO}_{2}$ to $\mathrm{MgO}$ via Eq. (4).

At zone $\mathrm{V}$, the mass fraction of magnesium addition is high and the equilibrium precipitation is $\mathrm{MgO}$. The mass fraction of $\mathrm{MgO}$ slightly increases by Eq. (5). 


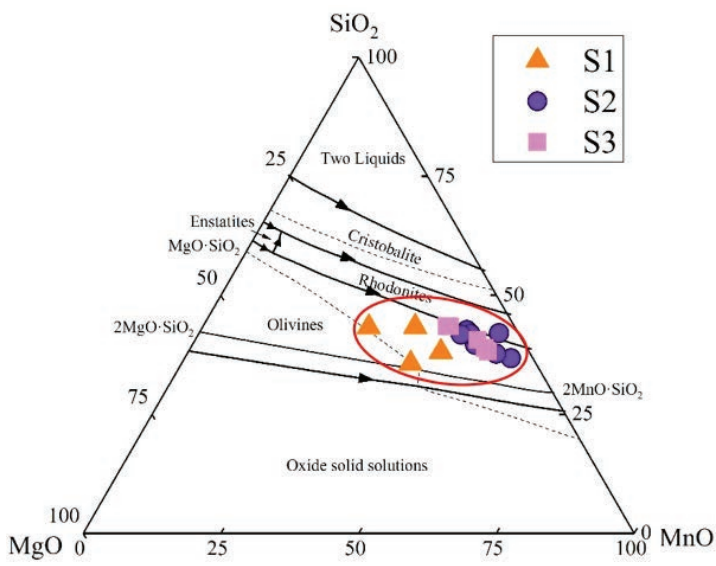

(a) Melt A

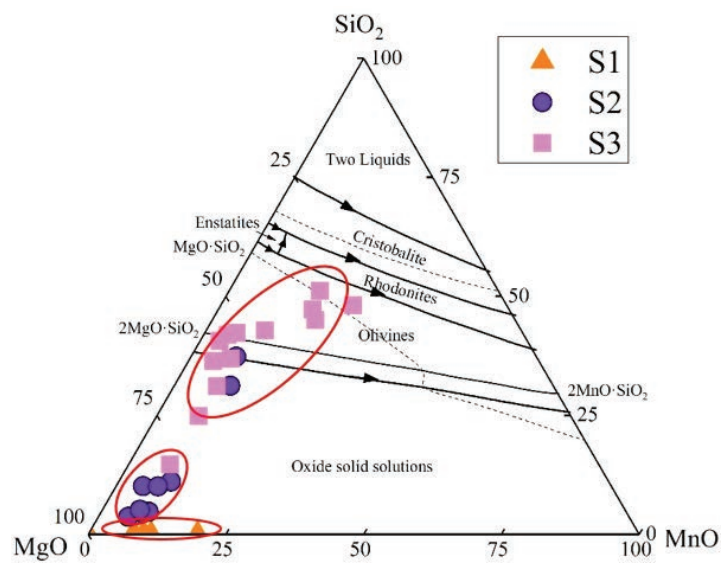

(b) Melt B

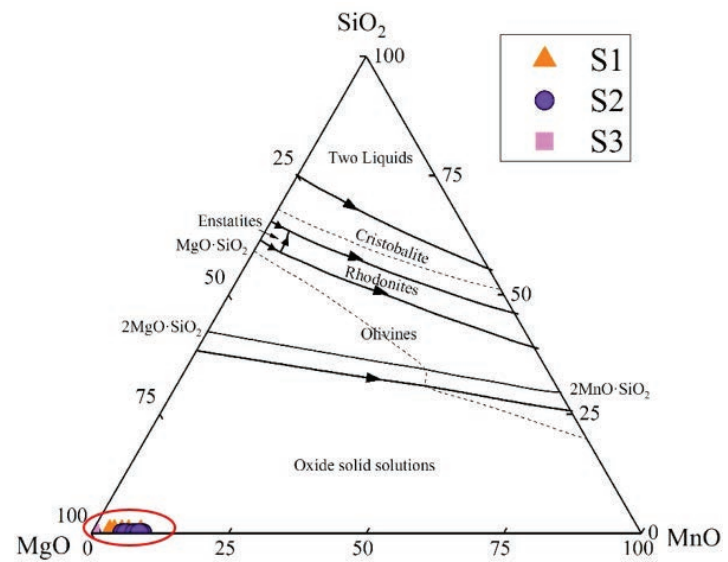

(c) Melt C

Fig. 9. Composition distribution of inclusions with holding time after magnesium addition. (Online version in color.)

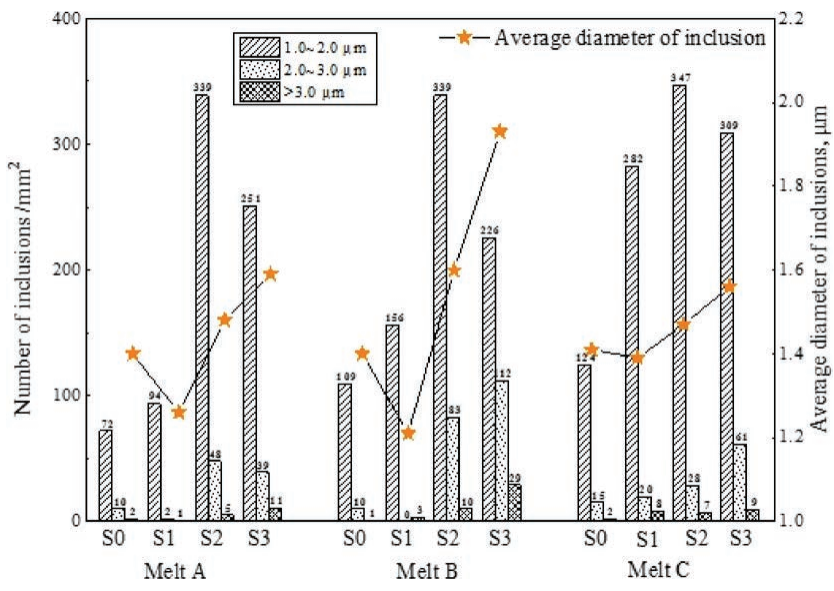

Fig. 10. Number and diameter of inclusions observed in all samples. (Online version in color.)

Based on the analysis mentioned above, the evolution process of equilibrium precipitations is $\mathrm{MnO}-\mathrm{SiO}_{2}(\mathrm{l}) \rightarrow$ $\mathrm{MgO}-\mathrm{SiO} 2-\mathrm{MnO}(\mathrm{l}) \rightarrow 2 \mathrm{MgO} \cdot \mathrm{SiO}_{2}(\mathrm{~s}) \rightarrow \mathrm{MgO}(\mathrm{s})$ with the increase of magnesium addition in $\mathrm{Mn}-\mathrm{Si}$ killed molten steel, which is in good agreement with the experimental results. Similar findings were reported in $\mathrm{Ti}-\mathrm{Mg}$ killed melts. ${ }^{17,18)}$

Based on the experimental results and thermodynamics of inclusions, the evolution mechanism is proposed in Fig. 12

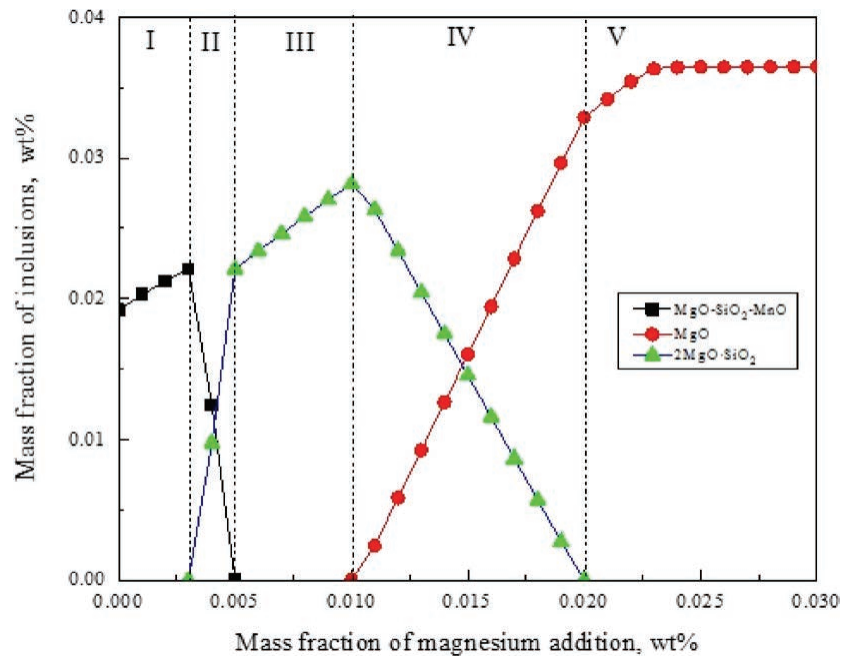

Fig. 11. Effect of magnesium content on the equilibrium precipitation of inclusions at $1873 \mathrm{~K}$. (Online version in color.)

and the details are described as followings.

In route 1, a small amount of magnesium is added to the molten steel and the equilibrium precipitation is $\mathrm{MgO}-$ $\mathrm{SiO}_{2}-\mathrm{MnO}$ liquid inclusion. $\mathrm{Mg}$ dissolves into the molten steel and then partly substitute for $\mathrm{Mn}$ and $\mathrm{Si}$ in $\mathrm{SiO}_{2}-\mathrm{MnO}$ deoxidization product. The modification of $\mathrm{SiO}_{2}-\mathrm{MnO}$ to $\mathrm{MgO}-\mathrm{SiO}_{2}-\mathrm{MnO}$ is given by Eq. (1). 
Table 4. Reactions at different zones.

\begin{tabular}{ccrc}
\hline Zones & Reaction & $\Delta G^{\circ} / \mathrm{J}^{-\mathrm{mol}^{-1}}$ & Equation \\
\hline $\mathrm{I}$ & $\mathrm{MnO} \cdot \mathrm{SiO}_{2}(\mathrm{l})+[\mathrm{Mg}]=\mathrm{MgO} \cdot \mathrm{SiO}_{2}(\mathrm{l})+[\mathrm{Mn}]$ & $-444094+106.29 T$ & $(1)$ \\
$\mathrm{II}$ & $2 \mathrm{MgO} \cdot \mathrm{SiO}_{2}(\mathrm{~s})+1 / 3[\mathrm{Si}]=4 / 3 \mathrm{MgO} \cdot \mathrm{SiO}_{2}(\mathrm{l})+2 / 3[\mathrm{Mg}]$ & $404544-135.52 T$ & $(2)$ \\
$\mathrm{III}$ & $2[\mathrm{Mg}]+[\mathrm{Si}]+4[\mathrm{O}]=2 \mathrm{MgO} \cdot \mathrm{SiO}_{2}(\mathrm{~s})$ & $-2106300+702.14 T$ & $(3)$ \\
$\mathrm{IV}$ & $4 \mathrm{MgO}(\mathrm{s})+[\mathrm{Si}]=2 \mathrm{MgO} \cdot \mathrm{SiO}_{2}(\mathrm{~s})+2[\mathrm{Mg}]$ & $808100-251.46 T$ & $(4)$ \\
$\mathrm{V}$ & {$[\mathrm{Mg}]+[\mathrm{O}]=\mathrm{MgO}(\mathrm{s})$} & $-728600+238.4 T$ & $(5)$ \\
\hline
\end{tabular}

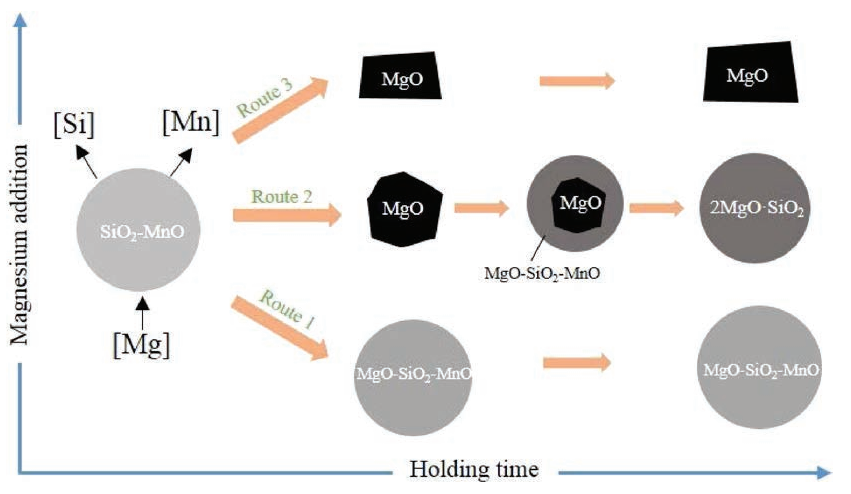

Fig. 12. Formation and evolution of inclusions by magnesium treatment. (Online version in color.)

In route 2, a medium amount of magnesium is added to the molten steel and the equilibrium precipitation is $2 \mathrm{MgO} \cdot \mathrm{SiO}_{2}$ solid inclusion. Different from route 1 , spherical $\mathrm{MgO}$ forms as intermediate product immediately after magnesium addition in route 2 . As $\mathrm{MgO}$ is unstable according to thermodynamics, $\mathrm{MgO}$ continues to react with the molten steel through Eq. (4) and eventually converts to $2 \mathrm{MgO} \cdot \mathrm{SiO}_{2}$ solid inclusion with holding time.

In route 3, an excessive amount of magnesium is added to the molten steel and the equilibrium precipitation is $\mathrm{MgO}$ solid inclusion. Rectangular $\mathrm{MgO}$ forms immediately after magnesium addition and keeps stable with holding time.

\section{Conclusions}

The effect of magnesium addition on the evolution of inclusions in Mn-Si killed molten steel has been studied by the laboratory experiments and thermodynamic calculation at $1873 \mathrm{~K}$. The main findings can be summarized as followings.

(1) Four types of inclusions are detected after magnesium addition, namely $\mathrm{MgO}-\mathrm{SiO}_{2}-\mathrm{MnO}$ liquid inclusion, $\mathrm{MgO}-\mathrm{SiO}_{2}-\mathrm{MnO}$ complex inclusion, $\mathrm{MgO}-\mathrm{SiO}_{2}$ and $\mathrm{MgO}$ system solid inclusion, which are in accordance with the result of thermodynamic calculation.

(2) The amount of magnesium added to the molten steel significantly influences the evolution of inclusions. Liquid inclusion of $\mathrm{MnO}-\mathrm{SiO}_{2}$ is promptly modified to $\mathrm{MgO}-\mathrm{SiO}_{2}-\mathrm{MnO}$ liquid inclusion with $0.0005 \%$ magnesium addition. As the amount of magnesium is increased to $0.0011 \%$, intermediate product $\mathrm{MgO}$ forms immediately and then gradually transforms to $\mathrm{MgO}-\mathrm{SiO}_{2}$ solid inclusion with holding time. While $\mathrm{MgO}$ solid inclusion keeps stable throughout with magnesium amount further increased to $0.0019 \%$.

(3) In the present magnesium treatment level, a medium amount of magnesium addition would lead to the precipitation of more large size inclusions.

\section{Acknowledgements}

The authors gratefully acknowledge the support from the National Natural Science Foundation of China (Grant No. NSFC 51674069) and the National Key R \& D Program of China (Grant No. 2017YFC0805100).

\section{REFERENCES}

1) K. Takai, J. Seki, E. Sakita and K. Takayama: Tetsu-to-Hagané, 79 (1993), 685 (in Japanese).

2) S. Zhou: Metallurgist, 57 (2013), 510.

3) K. Taguchi, O. N. Hideki, T. Usui, K. Marukawa, K. Katogi and H. Kosaka: ISIJ Int., 45 (2005), 1572.

4) B. Coletti, B. Blanpain, S. Vantilt and S. Sridhar: Metall. Mater. Trans. B, 34 (2003), 533.

5) W. Ma, Y. Bao, M. Wang and L. Zhao: ISIJ Int., 54 (2004), 536.

6) A. Ghosh: ISIJ Int., 48 (2008), 1552.

7) H. Itoh, M. Hino and S. Ban-Ya: Metall. Mater. Trans. B, 28 (1997), 953.

8) K. Fujii, T. Nagasaka and M. Hino: ISIJ Int., 40 (2000), 1059.

9) W. G. Seo, W. H. Han, J. S. Kim and J. J. Park: ISIJ Int., 43 (2003), 201.

10) X. D. Zou, D. Zhao, J. C. Sun, C. Wang and H. Matsuura: Metall. Mater. Trans. B, 49 (2018), 481.

11) G. Okuyama, K. Yamaguchi, S. Takeuchi and K. I. Sorimachi: ISIJ Int., 40 (2000), 121.

12) I. H. Jung, S. A. Decterov and A. D. Pelton: ISIJ Int., 44 (2004), 527.

13) L. Zhang, Y. Ren, H. Duan, W. Yang and L. Sun: Mater. Trans. B, 46 (2015), 1809.

14) S. Kimura, K. Nakajima and S. Mizoguchi: Metall. Mater. Trans. B, 32 (2001), 79

15) T. Zhang, Y. Min, C. Liu and M. Jiang: ISIJ Int., 55 (2015), 1541.

16) T. S. Zhang, Y. Min and M. F. Jiang: Can. Metall. Q., 54 (2015), 161.

17) H. S. Kim, C. H. Chang and H. G. Lee: Scr. Mater., 53 (2005), 1253.

18) C. H. Chang, I. H. Jung, S. C. Park, H. S. Kim and H. G. Li: Ironmaking Steelmaking, 32 (2005), 251.

19) B. Wen, B. Song, N. Pan, Q. Y. Hu and J. H. Mao: Ironmaking Steelmaking, 38 (2011), 577.

20) J. T. Li, Z. Y. Lu and S. X. Chen: J. Northeast Univ., 13 (1992), 451.

21) A. Karasev and H. Suito: Metall. Mater. Trans. B, 30 (1999), 249.

22) G. Eriksson, P. Wu, M. Blander and A. D. Pelton: Can. Metall. Q., 33 (1994), 13

$23)$ F. P. Glasser and E. F. Osborn: J. Am. Ceram. Soc., 43 (1960), 132.

24) H. Ohta and H. Suito: ISIJ Int., 46 (2006), 14.

25) R. Takata, J. Yang and M. Kuwabara: ISIJ Int., 47 (2007), 1379.

26) I. H. Jung: Calphad, 34 (2010), 332.

27) C. W. Bale, E. Belisle, P. Chartrand, S. A. Decterov, G. Eriksson, A. E. Gheribi, K. Hack, I.-H. Jung, Y. B. Kang, J. Melancon, A. D. Pelton, S. Petersen, C. Robelin, J. Sangster, P. Spencer and M-A. Van Ende: Calphad, 55 (2016), 1.

28) H. Shibata, T. Tanaka, K. Kimura and S. Y. Kitamura: Ironmaking Steelmaking, 37 (2010), 522.

29) T. Nishi and K. Shinme: Tetsu-to-Hagané, 84 (1998), 837 (in Japanese).

30) J. X. Cheng: Data Handbook for Steelmaking, Metallurgical Industry Press, Beijing, (2010), 651. 